\title{
Obstetric Capacity Strengthening in Ghana Results in Wide Geographic Distribution and Retention of Certified Obstetrician-Gynecologists: A Quantitative Analysis
}

\author{
Melani Kekulawala ${ }^{1}$, Ali Samba ${ }^{2}$, Yael Braunschweig ${ }^{1}$, Jacob Plange-Rhule ${ }^{3}$, Cornelius \\ Turpin $^{4}$, Timothy Johnson ${ }^{5}$, and Frank Anderson ${ }^{6}$ \\ ${ }^{1}$ University of Michigan School of Public Health \\ ${ }^{2}$ Korle Bu Teaching Hospital \\ ${ }^{3}$ Ghana College of Physicians and Surgeons \\ ${ }^{4}$ Komfo Anokye Teaching Hospital \\ ${ }^{5}$ University of Michigan Michigan Medicine \\ ${ }^{6}$ University of Michigan
}

October 4, 2021

\begin{abstract}
Objectives: Our primary objective to determine the cumulative retention of Ob/Gyns since the inception of the program, to determine the demographic and practice characteristics of all Ob/Gyns who have been trained by the Ghana postgraduate $\mathrm{Ob} /$ Gyn programs, and to compare the geographic distribution of Ob/Gyns throughout Ghana between 2010 when a prior study was conducted and the current practice locations of all graduates in 2017. Design: Cross-sectional, Quantitative Investigation Setting: Fieldwork for this study was conducted in Ghana between June 21, 2017, and August 20, 2017. Methods: A roster of certified Ob/Gyns, year certified, and email contact information was obtained from the Ghana College of Physicians and Surgeons, a roster of practice locations was obtained from Ghana Medical Board. Main Outcome Measures: retention of Ob/Gyns, geographic distribution of providers, fand comparisons between 2010 and 2017 Results: Significant geographic spread and increase in in-country medical programs have occurred over the seven-year period. In recent years, the Ghana College of Physicians and Surgeons surpassed that of the West African College of Surgeons. Conclusion: Establishing an Ob/gyn training program with national certification provides a cadre of certified Ob/Gyns that can be trained and retained in lowincome settings. Moreover, this allows for long term commitment in multiple relevant sectors that may serve to establish a comprehensive obstetric and gynecology capacity beyond urban centers.
\end{abstract}

Obstetric Capacity Strengthening in Ghana Results in Wide Geographic Distribution and Retention of Certified Obstetrician-Gynecologists: A Quantitative Analysis

Melani Kekulawala ${ }^{1,2}$, Ali Samba ${ }^{3}$, Yael Braunschweig ${ }^{1,4}$, Jacob Plange-Rhule ${ }^{5}$, Cornelius Turpin ${ }^{6}$, Timothy R.B. Johnson ${ }^{7}$, Frank W.J. Anderson*1,7

${ }^{1}$ University of Michigan, School of Public Health, Department of Health Behavior and Health Education

${ }^{2}$ University of Toledo, College of Medicine and Life Sciences

${ }^{3}$ Department of Obstetrics and Gynecology, University of Ghana

${ }^{4}$ Department of Primary Care and Population Health, Stanford University

${ }^{5}$ Ghana College of Physicians and Surgeons 
${ }^{6}$ Department of Obstetrics and Gynecology, Kwame Nkrumah University of Science and Technology

${ }^{7}$ Department of Obstetrics and Gynecology, University of Michigan

*Corresponding Author:

Frank W.J. Anderson

University of Michigan, Department of Obstetrics and Gynecology

Address: 1540 E Hospital Drive, Ann Arbor, MI

Email: fwja@umich.edu

Phone: (734) 904-1852

Running Title: Obstetric Capacity Strengthening in Ghana

\section{Hosted file}

Main Body.docx available at https://authorea.com/users/436918/articles/538918-obstetriccapacity-strengthening-in-ghana-results-in-wide-geographic-distribution-and-retentionof-certified-obstetrician-gynecologists-a-quantitative-analysis

\section{Hosted file}

Table.docx available at https://authorea.com/users/436918/articles/538918-obstetriccapacity-strengthening-in-ghana-results-in-wide-geographic-distribution-and-retentionof-certified-obstetrician-gynecologists-a-quantitative-analysis

\section{Hosted file}

Figure 1.docx available at https://authorea.com/users/436918/articles/538918-obstetriccapacity-strengthening-in-ghana-results-in-wide-geographic-distribution-and-retentionof-certified-obstetrician-gynecologists-a-quantitative-analysis

\section{Hosted file}

Figure 2_landscape.docx available at https://authorea.com/users/436918/articles/538918obstetric-capacity-strengthening-in-ghana-results-in-wide-geographic-distribution-andretention-of-certified-obstetrician-gynecologists-a-quantitative-analysis 